SÍNTESE: REVISTA DE FILOSOFIA

DECLARAÇÃO DE DIREITO AUTORAL

Os autores mantêm os direitos autorais e concedem à revista o direito de primeira publicação, com o trabalho simultaneamente licenciado sob a Creative Commons Attribution License.

Fonte:

http://www.faje.edu.br/periodicos/index.php/Sintese/about/submissions\#copyrightNotice. Acesso em: 15 jun. 2016. 
Síntese - Rev. de Filosofia

v. 39 N. 123 (2012): 119-141

\section{ASCENSÃO E DECADÊNCIA DA EPISTEMOLOGIA DIVINA}

(The rise and fall of divine epistemology)

Evaldo Sampaio *

RESUMO: Trata-se de examinar a parábola da Morte de Deus enquanto uma crítica do conhecimento. Seguindo-se sua formulação na filosofia de Friedrich Nietzsche, pretende-se identificar a constituição do que se designa por epistemologia divina, sua ascensão e agora declarado declínio. Para tanto, caracteriza-se a singularidade do tipo de abordagem que Nietzsche concede à questão e se discute sua probidade. Entende-se que tal investigação pode fornecer recursos conceituais para debates contemporâneos nos quais, como se sugere, ocultam-se estruturas morais e cognitivas que reforçam aquilo que se propõem a abandonar.

Palavras-chave: Filosofia Extramoral, Epistemologia da Religião, Morte de Deus, Ateísmo, F. Nietzsche.

Abstract: The article examines the parable of the Death of God as an epistemological issue. In order to achieve this purpose, the work tries to identify in Friedrich Nietzsche's philosophy the constitution of what could be called divine

\footnotetext{
* Professor Adjunto do Departamento de Filosofia da Universidade de Brasília, Brasília, DF, Brasil. Uma versão preliminar deste ensaio foi apresentada no I Congresso Brasileiro de Filosofia da Religião, Brasília, 2005. Artigo submetido a avaliação no dia 25/02/2011 e aprovado para publicação no dia 18/06/2011.
} 
epistemology, its rise and current decline. To do so, the singularity of Nietzsche's approach to the issue is characterized and its consistence discussed. It is understood that such investigation can supply conceptual resources for a contemporary debate in which, as suggested, cognitive and moral structures are hidden that reinforce what is to be abandoned.

Key-words: Extra-moral Philosophy, Epistemology of Religion, Death of God, Atheism, F. Nietzsche.

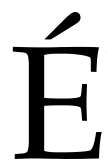
bastante conhecida a polêmica de Friedrich Nietzsche para com o cristianismo. Mais do que conhecida, esta é ainda reconhecida em sua virulência e periculosidade quando mesmo Bento XVI, na encíclica inicial de seu pontificado, fez de Nietzsche o primeiro filósofo citado e combatido como opositor dos mais elevados ideais ${ }^{1}$. De fato, Nietzsche chega a proclamar, em sua autobiografia intelectual (ironicamente intitulada "Ecce Homo") ${ }^{2}$, que ele se distingue de todo o resto da humanidade por haver "descoberto" a moral cristã e que a cegueira moral ante o cristianismo é um "crime contra a vida" um crime contra a vida? Por qual critério, se é que há algum, Nietzsche poderia sentenciar os cristãos como "decadentes"? Seria este o discurso de um mero ateu ou de algum "cristão desencantado"? Pretendo aqui reconstituir a intuição filosófica de Nietzsche quanto ao modo de vida cristão a partir de uma das mais controversas experiências de seu pensamento, no caso, a "parábola da morte de Deus". Tal controvérsia já se dá inclusive em relação à importância hermenêutica que se lhe deva atribuir, pois embora Nietzsche a apresente em somente duas seções de uma única obra, A Gaia Ciência, e a retome diretamente apenas no Assim Falou Zaratustra, a recepção crítica lhe conferiu - com ou sem razão - uma relevância decisiva para a filosofia de seu autor. Mais precisamente, Nietzsche sequer é o criador desta expressão e nem o carrasco de Deus, porém aquele que supostamente anuncia um delito já consumado. Aceitando-se tal condição, inevitavelmente se é levado a perguntar "quem são afinal os assassinos do Deus cristão?" e, por conseguinte, "quais as consequências do teocídio?".

A parábola da morte de Deus diz respeito à ideia de que a crença na divindade cristã está em manifesto declínio, concluindo disso a extrema relevância de analisar as sequelas deste falecimento para nossa condição

${ }^{1}$ BENTO XVI, Deus é Amor, p. 10.

${ }^{2}$ Trata-se da sentença pela qual, segundo o Evangelho de São João, cap. XIX, Pilatos apresenta Cristo aos Judeus.

${ }^{3} \mathrm{EH}$, "Por que sou um destino" $\$ 7$. 
existencial. Concordo assim parcialmente com Walter Kaufmann quando este a interpreta antes como um diagnóstico da civilização contemporânea do que como uma especulação metafísica acerca da realidade última das coisas, divergindo igualmente daqueles que a acusam de ser uma simples declaração de ateísmo ${ }^{4}$. O que me impede de acompanhar irrestritamente a leitura de Kaufmann é que, se é correto que Nietzsche não propõe ali uma especulação metafísica sobre a realidade última das coisas, parece-me que parte de seu diagnóstico da civilização contemporânea quanto ao declínio da crença em Deus supõe um desenvolvimento que remonta a autores que realizaram aquelas primeiras meditações. Por sua vez, uma simples declaração de ateísmo perde de vista o que o próprio Nietzsche deixara claro quanto a si, já que a sua refutação histórico-genealógica lhe é relevante e talvez "definitiva" não por conduzi-lo a esta ou aquela contraprova acerca da existência de Deus, mas por agora permitir "separar o preconceito teológico do moral"5. Assumo então tal diagnóstico como filosófico e condicional, escolhendo-o como meio de exposição basicamente por considerá-lo ainda fecundo para uma leitura intensa de uma condição ainda não assimilada em todas as sutilezas. Uma destas sutilezas reside no seu aspecto "epistemológico".

O que significa considerar epistemologicamente a morte de Deus? Trata-se de formulá-la enquanto uma "crítica ao conhecimento". Minha sugestão, a ser corroborada adiante, é interpretá-la como um fenômeno do âmbito moral (ou "extramoral") com repercussões linguístico-cognitivas. Entretanto, deve-se ter em mente que tal investigação em Nietzsche assume diferentes facetas ou perspectivas e, destas, a mais fecunda é a que concebe a moral como uma "doutrina das relações de dominação sob as quais se origina o fenômeno vida" ${ }^{\prime \prime}$. Dito de outro modo: embora Nietzsche empregue a noção de moralidade em mais de uma acepção, aquela que lhe seria superior é a que assume a moral como uma perquirição das hierarquias de valores que constituem um modo de existir ${ }^{7}$. O valor do conhecimento

\footnotetext{
${ }^{4}$ KAUFMANN, W. Nietzsche, Philosopher, Psychologist, Antichrist, cap. 3. Ali também se esclarece que a ideia de morte de Deus estava presente em autores anteriores a Nietzsche, como Hegel e especialmente Heinrich Heine - autor admirado por Nietzsche.

${ }^{5}$ GM, prólogo §3.

6 BM $\$ 19$.

${ }^{7}$ Pode-se organizar e mesmo hierarquizar patamares distintos nos quais Nietzsche opera com a noção de moralidade. $\mathrm{O}$ mais geral seria aquele que entende (i) a moral como um sentimento acerca do costume, ou seja, uma disposição pela qual nos relacionamos com "a idade, santidade e indiscutibilidade" das práticas que nossa comunidade instituiu como "boas" ou "más" [A §19]. (ii) Quando adjetiva a moralidade com termos tais como "moral da compaixão" [GM, prólogo §5], "moral cristã" [EH, "Por que sou um destino" §4-8] ou "moral decadente" [A §15], Nietzsche se refere à moral do cristianismo (ou, excepcionalmente, a alguma moralidade de cunho religioso que lhe soe aparentada à cristã, como a budista [A §20]). (iii) Já quando estabelece a separação entre "pré-moral", "moral" e
} 
consiste no lugar que este ocupa nestas hierarquias e, por conseguinte, na força que nelas exerce. Daí por que, pela ótica de uma "gaia ciência", "a força do conhecimento não está no seu grau de verdade, mas [...] no seu grau de incorporação, em seu caráter de condição para a vida" ${ }^{\prime 8}$. É por estas ditas relações de dominação que pretendo analisar o alcance epistêmico da parábola da morte de Deus. Nessa estrutura vital, uma "teoria do conhecimento" assume outra tonalidade, distanciando-se de uma disciplina que se contenta com a busca pela origem e alcance do que podemos conhecer. Sem dúvida Nietzsche não elaborou o que estamos acostumados a designar por epistemologia em sentido estrito. Se por um lado concordo com os que consideram inócuo formular uma epistemologia nietzscheana em sentido forte, pois sua boa-nova para o conhecimento está justamente em trazer à tona os pressupostos que o condicionam e valoram, por outro julgo que há pertinência em extrair de suas intuições acerca de como conhecemos seus componentes "ante-epistêmicos" (mas que não são "antiepistêmicos"). Se explorado, este âmbito poderá fornecer um fio condutor para se desvendar como, quanto à anunciada morte de Deus, os algozes se tornam também vítimas de seus próprios atos. Opto assim por refletir acerca do que designo como ascensão e decadência da epistemologia divina sem onerar mais do que o necessário sua conjectura histórico-filosófica ou mesmo sua suposta relevância hermenêutica na obra à qual pertence. Concentrarei minha atenção em sua formulação original n' $A$ Gaia Ciência, subordinando-lhe passagens de outros escritos quando relevante?

Retomando-se A Gaia Ciência, lê-se que os homens são de tal maneira que "depois que Buda morreu, sua sombra ainda foi mostrada numa caverna durante séculos - uma sombra imensa e horrível". Do mesmo modo, embora Deus esteja morto, é provável que "durante séculos ainda haverá cavernas

\footnotetext{
"extramoral ou imoral" [BM §32], Nietzsche designa como período moral da humanidade aquele no qual o valor de uma ação era medido inicialmente pela sua origem (quando da "moral dos senhores") e, posteriormente, passou a sê-lo pela intenção do agente (pela assim instituída "moral dos escravos"). (iv) Por fim, em sentido superior, quando Nietzsche caracteriza a moral como doutrina das relações de dominação sob a qual se origina 0 fenômeno vida, torna-a sinônimo do que nomeia de "extramoral ou imoral". Trata-se assim de um plano segundo o qual o valor de uma ação está naquilo que nela é "nãointencional" - sendo o "não-intencional" compreendido como a "vontade" que persiste às atitudes. Este uso polissêmico da noção de moralidade, que chega até a igualar "moral" e "imoral" em certas conjunturas, se ambíguo em relação ao conjunto da obra de Nietzsche, nem por isso deixa de ser preciso quando se atenta para as situações específicas de sua utilização - embora isso exija, como Nietzsche costumeiramente requer, maior atenção de seus leitores. O que me leva a propor a quarta acepção de moralidade como superior em relação ao todo do pensamento de Nietzsche é que, segundo o próprio, aí reside a diferença e distância de sua abordagem frente aos demais moralistas [BM §32].

${ }^{8}$ GC $\$ 110$

${ }^{9}$ Há certa discussão especializada sobre o estatuto do material filosófico assinado por Nietzsche. Tal debate, de maneira um tanto simplificada, pode ser descrito como um desacordo acerca da diferença ou igualdade de relevância entre os escritos publicados e/
} 
em que sua sombra será mostrada" e, por isso, "nós teremos que vencer também a sua sombra!"10. Inicialmente não me parece um abuso de interpretação sugerir que a recorrência a "sombras" e "cavernas" nos remete a Platão e a seu mais famoso mito. O mito da caverna, dentre outras coisas, é uma metáfora da possível ascensão do homem ao conhecimento. No trecho, afirma-se que Deus está morto e que sua sombra talvez ainda será

ou preparados para publicação pelo próprio autor e um conjunto bastante heterogêneo de trabalhos que reúnem anotações dispersas, aulas e conferências quando de seu professorado em Basiléia, versões preliminares de parte da obra autorizada, poemas, além de pequenos ensaios e artigos. Quanto a estes trabalhos que não foram publicados pelo próprio Nietzsche, pode-se, com Walter Kaufmann, dividi-lo em três categorias: i) trabalhos que Nietzsche preparou para publicação, mas que não publicou devido ao colapso de 1889 (AC, EH, NW, NCW), que devem ser tratados como obras; ii) Notas de aulas quando do professorado em Basileia, que apresentam importantes informações sobre sua compreensão da Antiguidade grega e que não mostram grandes dificuldades hermenêuticas; iii) Uma massa de fragmentos e notas que incluem ensaios inconclusos, breves anotações, esquemas e projetos de obras por serem redigidas. (iii) pode ser dividido em duas classes: (iii.1) o material que nunca fora publicado em nenhuma obra; (iii.2) notas que foram aproveitadas com modificações em obras. (iii.2) não revela as concepções finais de Nietzsche, mas apenas os seus estágios de preparação. O material de (iii.1) precisa ser distinguido radicalmente das obras, uma vez que não se sabe como este seria utilizado ou mesmo se o seria. Estas notas, das quais se originou o "apócrifo" Vontade de Poder e cujas circunstâncias de edição são detalhadamente examinadas por Kaufman, apesar de filosoficamente interessantes, foram superestimadas no passado, especialmente por Elizabeth FörsterNietzsche, irmã e detentora do espólio de Nietzsche após o colapso do autor, que pela ocultação do Nachlass tentou impor, por mera autoridade, que naqueles manuscritos, que originaram a suposta magnum opus, estavam às ideias centrais de seu irmão. Compartilho plenamente da posição metodológica de Kaufmann que subordina a interpretação do corpus não publicado e/ou não preparado para publicação por Nietzsche às obras por ele organizadas/editadas. Logo, por "obras" de Nietzsche entendo aqui apenas os escritos que este publicou e/ou preparou para publicação. Portanto, eventuais formulações extraídas de notas de trabalho, recurso utilizado por vezes indiscriminadamente pela recepção especializada, serão aqui desconsideradas. Ainda sobre a questão dos "fragmentos póstumos", Kaufmann [op. cit., p. 76-77] narra o uso ideológico destes por Alfred Bäumler, catedrático da Universidade de Berlin e "intérprete oficial" de Nietzsche para os nazistas, cujo Nietzsche, Der Philosoph und Politiker [1931] defende que o autor não queria realmente dizer o que escreveu em seus livros, estando sua "verdadeira" filosofia nos manuscritos. Para além do ardil de suprimir as contradições que sua interpretação encontrava frente às obras do interpretado, o procedimento de Bäumler mostra como a supressão da unidade de pensamento de Nietzsche, superficialmente justificada por seu estilo aforismático, permite que sobre ele recaia praticamente todo tipo de leitura. Sobre o uso tendencioso das notas preparatórias de Nietzsche por Alfred Bäumler, ver também Mazzino Montinari, Interpretações Nazistas. Sem o perceber, parte substancial da recepção crítica, embora recuse as leituras de Elizabeth Förster-Nietzsche e Bäumler, reproduz por vezes acriticamente as mesmas estratégias que, adequadamente conduzidas, dão consistência aos devaneios hermenêuticos destes primeiros intérpretes. Uma objeção mais ampla quanto ao uso hermeneuticamente inadequado dos ?fragmentos póstumos? de Nietzsche, bem como uma inaudita interpretação de sua filosofia com base nos escritos publicados e/ou preparados para publicação, encontra-se em SAMPAIO, E. Por que Somos Decadentes? Afirmação e Negação da Vida Segundo Nietzsche.

10 GC $\$ 108$. 
mostrada em cavernas. Esta sombra, portanto, seria a de um cadáver. Trata-se do reflexo de algo inerte, sem vida, mas que, por sua "aparência", ainda estaria a orientar o caminho dos homens. Uma vez que a sombra de Deus não é o próprio Deus, trata-se, em linguagem platônica, de sua cópia. Contudo, se não há mais a Ideia que origina a cópia, pois Deus está morto, não seria sequer o caso de falarmos numa cópia e sim, novamente em linguagem platônica, de um simulacro ${ }^{11}$. O simulacro é algo sem o lastro da Ideia, o desmedido, o falso em sua forma mais depurada. Convém notar que, no mito platônico, a divindade ou o conhecimento das coisas divinas se dá com o abandono das sombras e que, na parábola de Nietzsche, discute-se justamente o abandono da crença nestas sombras. A sombra é um decalque da imagem inicial, simplificação que apenas lhe indica os contornos, um sinal: a sombra é como um signo de Deus. Mas, se não há mais o objeto que projeta a sombra, esta se torna um signo de um vazio, um discurso, quando muito, sobre si mesmo. De certo modo, não poderíamos entender como "sombras de Deus" o uso de um vocabulário que perdeu sua referência? Signos que nada mais simbolizam? Vencer a sombra de Deus, nesta acepção, não seria equivalente a superar um modo de pensar, simbolizar e conhecer? Deus pode estar morto, mas suas sombras, i.e., os modelos de pensamento e discursos que Dele se originam, ainda persistem nas "cavernas".

Assim expresso, parece que ultrapasso - e muito - as inferências que a citação anterior me autorizaria. Porém, se nos conduzirmos ao $\$ 125$ da mesma Gaia Ciência, os aparentes excessos desta leitura se tornam, no mínimo, justificáveis. Nessa seção, intitulada "o homem louco", Nietzsche elabora um comentário sobre um indivíduo que, certa manhã, acende uma lanterna e se põe desesperadamente a gritar no mercado: "Procuro Deus?!". Uma vez que lá se encontravam muitos que não criam em Deus, o suplício do homem desperta gargalhadas. "Ele está perdido?", "Ele se escondeu?", "Embarcou num navio?", "Está com medo de nós?", ironizaram alguns. A isto o louco responde que Deus não fora a lugar nenhum, mas sim que estava morto e que nós o matamos! E, para um público agora surpreso, pergunta se

“[...] Não ouvimos o barulho dos coveiros a enterrar Deus? Não sentimos o cheiro da putrefação divina? [...] Deus está morto! Deus continua morto! E nós o matamos! Como nos consolar, assassinos dentre os assassinos? O mais forte e mais sagrado que o mundo até então possuíra sangrou inteiro sob nossos punhais - quem nos limpará este sangue? [...] Que rios expiatórios, que jogos sagrados teremos de inventar? A grandeza deste ato não é demasiado grande para nós?".

${ }_{11}$ Quanto à distinção entre "cópia" e "simulacro", ver PLATÃO, O Sofista, 236b. Uma interpretação destes conceitos apropriada para o contexto aqui em questão está no ensaio de Gilles Deleuze, "O simulacro e a filosofia antiga", apêndice I do seu Lógica do Sentido. 
Diante do silêncio e da desorientação dos ouvintes, o "louco" avalia que suas palavras chegaram cedo demais, que os homens não estão prontos para se tornarem conscientes do que fizeram, pois "os atos, mesmo depois de feitos, precisam de tempo para serem vistos e ouvidos"12. Convém suspeitar que o louco do mercado provavelmente foi inspirado por Diógenes, filósofo da Escola Cínica que, segundo se relata, andava durante o dia com uma lanterna acesa dizendo "procuro um homem!". Aos que eventualmente responderam aos seus brados, ele declarava: "Chamei homens e não canalhas!". Por estas e outras razões, Platão, alvo frequente das zombarias de Diógenes, descrevera-o como "um Sócrates demente"13. Aquele que anuncia a morte de Deus não seria um insano justamente aos olhos dos "canalhas"? E não seria preciso um Sócrates demente para tal anunciação?

É digno de nota que a parábola da morte de Deus é dirigida não para os crentes e sim para os ateus. Por isso, Nietzsche parece indicar que o óbito divino não é em princípio um caso para os homens de fé, porém antes um problema para os descrentes. Os crentes ainda não assumiram que Deus está morto. Sua, digamos, "ingenuidade", os mantêm como que alheios ao teocídio. $\mathrm{O}$ "perigo" imediato diz respeito àqueles ateus que, apesar de descrentes, ainda não compreenderam em todas as suas consequências o que realmente significa um mundo sem Deus e vivem como se nada ou quase nada tivesse sido alterado. O problema da morte de Deus consiste então em se tomar consciência das implicações de se ver o mundo com olhos estritamente mundanos ou, mais propriamente, sem a distinção entre o divino e o mundano.

O século XIX marca, para o Ocidente, tanto a consolidação da investidura positiva da ciência como autoridade institucional dos saberes quanto o consequente enfraquecimento da religião neste plano. Com isso, as decorrências de uma doutrina a favor ou contra a confiança religiosa se tornaram, progressivamente, quase que indiferentes para se avaliar o mérito de uma pesquisa. $\mathrm{O}$ fato de um dado pensamento confirmar ou refutar a crença em Deus e em seus atributos não é mais uma medida do valor ou da verdade deste pensamento. Entretanto, tal restrição tem lá seus embustes. O criticismo é aqui um caso exemplar. Nietzsche acusa Kant de ter criado um "além lógico" para salvaguardar Deus, a imortalidade e a liberdade da alma ${ }^{14}$. Com a distinção entre o que podemos pensar e o que podemos conhecer, abriu-se, como o próprio Kant fora o primeiro a confessar, um espaço para a fé15. Isto significa que as discussões acerca da

\footnotetext{
12 GC, §125.

${ }^{13}$ DIOGENES LAERTIUS. Vidas e Doutrinas dos Filósofos Ilustres, livro VII, 20-81.

${ }^{14}$ A, prefácio 3 .

${ }^{15}$ KANT, I. Critica da Razão Pura, prefácio à segunda edição.
} 
legitimidade das convicções teológicas abandonam o campo daquilo que podemos racionalmente deliberar. Já em sua Crítica da Razão Prática, Kant concebe Deus e a imortalidade da alma como condições da aplicação de uma vontade moralmente determinada ao "objeto" que lhe é facultado a priori, a saber, o "Sumo Bem". Embora teoricamente estes conceitos permaneçam incognoscíveis, a sua possibilidade pode e deve ser admita no âmbito prático - e, desse modo, aquilo que lhe é condição necessária adquire assim realidade objetiva ${ }^{16}$. Não surpreende então que Nietzsche denuncie que Kant não precisaria da Crítica da Razão Pura caso não cultivasse o projeto de defender Deus dos intermináveis debates metafísicos para, logo em seguida, reafirmá-lo com ainda maior dignidade como essencial ao aspecto prático da Razão ${ }^{17}$. Julgo que tal estratégia pode ser interpretada como uma transposição do chamado argumento do desígnio de um terreno ontológico para o transcendental. Deus não se mostra evidente porque a forma como o Mundo é assim, nos diz; mas Ele é necessário pela estrutura a priori que determina como concebemos e agimos no Mundo. Por artimanha filológica, naquilo que Kant considera inerente à própria constituição do sujeito, Nietzsche vê simplesmente uma superstição gramatical.

Sabe-se das profundas alterações de sentido operadas na língua latina quando de sua adesão ao cristianismo. O professor Silvio Elia destaca como "fides", que antes significava tão-só "lealdade", passa a designar "fé"; "salus", que significava "bem-estar", denota no latim cristão "a salvação da alma"; "spiritus", tradução do grego "pneuma", desloca seu sentido original de "sopro" para uma acepção imaterial; "peccare", que indicava "erro" se torna "pecar"; etc $^{18}$. Não se deve esquecer que as línguas europeias que se desenvolveram do latim não o fizeram por seu registro clássico, mas sim por seu registro cristão. Daí que a ascensão da epistemologia divina remete a uma hipóstase semântica da oposição entre imanência e transcendência que passa então a iluminar a práxis estabelecida, subvertendo-a. E a dificuldade que agora se enfrenta é que tais distinções teológicas estão de tal modo arraigadas às línguas "cristãs" que uma reminiscência de Deus, o que antes chamei de "sombras", parece persistir no âmbito "prático" mesmo entre aqueles que não mais creem em sua referência e valor. Daí o perigo que assola principalmente os novos ateus, o niilismo, porquanto tudo se passa para estes como se sua forma de representação epistêmico-linguística fosse um dizer acerca do nada. Tal risco então é estrutural, pois como superar uma figuração da realidade agora em descré-

\footnotetext{
${ }^{16}$ KANT, I. Crítica da Razão Prática, prólogo. Vale destacar que esta interpretação, inicialmente difundida por Leonard Reinhold, embora contestada por alguns, recebeu aprovação do próprio Kant, como revela Oswaldo Market em seu prefácio à edição portuguesa da Recepção da Crítica da Razão Pura.

17 A, prólogo 33 .

${ }^{18}$ ELIA, S. Preparação à Linguística Românica, cap. 6.
} 
dito, mas que se repõe celestialmente (ou transcendentalmente) a cada frase que se diz? Parece ser isto o que Nietzsche tem em vista quando receia que jamais nos livraremos de Deus enquanto ainda acreditarmos na "gramática"19. Kant, mesmo que por caminhos tortos, constatou corretamente que a moral e, por conseguinte, a forma de vida moderna, é indissociável de Deus. Apóstolo dos valores de seu tempo, restava-lhe insistir na fundamentação racional desta necessidade ${ }^{20}$. Como bem destaca Gerard Lebrun, o próprio Kant reconhece esta posição quando nos diz ser um absurdo interpretar sua metafísica dos costumes como a criação de uma nova moralidade, já que se trata unicamente da legitimação daquilo que "todos já sabem" ${ }^{21}$. Daí Nietzsche o sentenciar como um "funcionário da filosofia", i.e., alguém que promove valores que não criou. Por entender que os verdadeiros filósofos são "comandantes e legisladores" 22 de relações de dominação sobre as quais se origina o fenômeno vida, Nietzsche precisa se desvencilhar do criticismo, o que faz não por uma nova e sagaz resposta ao problema que ali é o caso, mas por sua substituição e elevação a outro patamar. É por essa nova perspectiva que já "é tempo de substituir a pergunta kantiana" sobre "como são possíveis juízos sintéticos a priori?" por outra, a saber: "por que é necessária a crença em tais juízos?", ou seja, para que fins de conservação "é preciso acreditar que tais juízos são verdadeiros" ?23 Em vez de questionar-se sobre a fundamentação e/ou verdade dos juízos sintéticos a priori, Nietzsche julga ser mais relevante perguntar sob quais condições e circunstâncias eles se originaram, bem como o que em nós exige algo fundamentado e/ou verdadeiro. Isto significa avaliar se "tais juízos obstruíram ou promoveram o crescimento do homem", sendo assim "indícios de miséria, empobrecimento, degeneração da vida", ou "ao contrário, revela-se neles a plenitude, a força, a vontade de vida, sua coragem, sua certeza, seu futuro" ${ }^{\prime 24}$. Ou seja, trata-se de perguntar sobre o valor dos juízos sintéticos a priori quanto às relações de dominação sob as quais se origina, conserva e fortalece o fenômeno vida.

A parábola da morte de Deus anuncia as implicações funestas da conservação de um modelo de pensamento, mesmo depois que seu alicerce semântico-existencial desaparecera. E tal problema se manifesta de maneira mais urgente naqueles que se autodenominam ateus, porque, apesar de expurgarem Deus no âmbito teológico, ainda o mantêm como uma ausência manifesta no nível epistêmico-linguístico. Tudo leva a crer que uma

\footnotetext{
${ }^{19}$ CI, III $\$ 5$.

20 BM $\$ 112, \S 169$.

${ }^{21}$ LEBRUN, G. Kant e o Fim da Metafísica, p. 5.

${ }^{22} \mathrm{BM} \S 211$.

${ }^{23} \mathrm{BM} \$ 11$.

${ }^{24} \mathrm{GM}$, prólogo 3 .
} 
intuição semelhante conduziu, décadas depois, Martin Heidegger a sentenciar toda a tradição do pensamento Ocidental - inclusive Nietzsche como uma ontoteologia ${ }^{25}$ e, mais recentemente, Henry Allison, discordando parcialmente de Heidegger, a sugerir que Kant teria sido o primeiro a identificar o papel que um Ser absoluto desempenha naqueles que assumiram, quanto ao que podemos conhecer, alguma espécie de realismo transcendental ${ }^{26}$ - posição distinta do idealismo transcendental kantiano. Tenho ressalvas quanto à extensão do argumento de Heidegger e, pelo que se disse acima, da absolvição ontoteológica de Kant; porém tais exemplos parecem corroborar a relevância da decadência da epistemologia divina ${ }^{27}$.

${ }^{25}$ HEIDEGGER, M. "Identidade e Diferença". Sabe-se que o termo "ontoteológica" foi proposto originalmente por Immanuel Kant em estreita relação com a "cosmoteologia" e de modo a distinguir dois tipos de "teologia transcendental" (Crítica da Razão Pura, A629-A640). Todavia, o emprego deste é alterado por Heidegger, para quem se trata de um sinônimo de "metafísica".

${ }^{26}$ Cf. ALLISON, H. Kant's Transcendental Idealism.

${ }^{27}$ Cabe esclarecer que o declínio da crença em Deus não seria um mero dado histórico ou sociológico. Afinal, Nietzsche não cita nenhum registro dessas áreas para lhe justificar os argumentos. E não o faz simplesmente porque o diagnóstico quanto ao declínio da epistemologia divina é, como inclusive não poderia deixar de sê-lo, "epistêmico" ou talvez "ontoepistêmico". Há maneiras distintas de se traçar o movimento de pensamento que conduz ou embasa tal diagnóstico. No que se segue, apresento uma que me parece mais instigante e de acordo com os antagonismos da filosofia de Nietzsche. Descartes, na quarta parte de seu Discurso do Método, dissera que as ideias claras e distintas apenas poderiam ser um critério de verdade se se aceitasse a existência de Deus; caso contrário, estas noções permaneceriam apenas subjetivas. Como a existência de Deus no referido Discurso se "comprovara" sobretudo pela necessária relação entre causa e efeito - já que seres finitos não poderiam pensar, como nós efetivamente pensamos, um Ser infinito sem que Ele fosse a causa necessária de tal juízo -, David Hume [Tratado da Natureza Humana, primeira parte], ao mostrar a ausência de necessidade nas relações de causa e efeito mesmo em relação às ideias claras e distintas, eliminou um componente decisivo da estrutura conceptual da prova cartesiana da existência de Deus. Desperto por Hume quanto à improcedência da necessidade objetiva das relações de causa e efeito que até ali guiaram toda a metafísica, Kant [Prolegômenos a toda Metafísica Futura, prefácio], como dito acima, confere à ideia de Deus um estatuto "regulador", ao considerar que esta não é necessária pela forma como o Mundo é, mas sim pelas estruturas transcendentais que constituem a priori o nosso conhecimento e ação no Mundo. A relevância de tal passo seria alcançar em outro patamar quase tudo que até ali os metafísicos buscaram pelo termo "Deus" (e também "liberdade" e "alma") com a vantagem de fornecer um fundamento crítico e conceptual inalcançável por aqueles. O que percebeu em seguida um dos mais argutos leitores de Kant, Arthur Schopenhauer, foi que "[...] nos três incondicionados [Deus, alma, liberdade] - aos quais, conforme Kant, deve chegar toda razão, seguindo suas leis essenciais - encontramos de novo os três objetos principais em torno dos quais girou toda a filosofia sob influência do cristianismo, dos escolásticos a Christian Wolf. Por mais acessíveis e coerentes que se tenham tornado tais conceitos por via de todos aqueles filósofos e agora pela razão pura, de maneira alguma é por aí certo que semelhantes conceitos, sem revelação, tivessem de provir do desenvolvimento de toda razão, como um produto próprio a sua natureza. Para decidir isso seria necessário pedir ajuda à investigação histórica e pesquisar se os povos antigos e não europeus, em especial os hindustânicos, 
Pode-se então, esquematicamente, falar de três paradigmas filosóficos de investigação sobre Deus. O primeiro seria uma reflexão ontológica acerca da Divindade, que argumenta contra ou a favor de Sua existência, como se vê tanto em autores medievais, como Santo Anselmo e Santo Tomás de Aquino, quanto em modernos como Descartes e Leibniz. Um segundo paradigma consiste num debate sobre a legitimidade da crença em Deus, a princípio independente do fato de Sua existência, que assume formulações distintas seja em Hume (história natural, psicológica) ou na filosofia crítica de Kant (princípio regulativo, transcendental). O terceiro paradigma, no qual Nietzsche e provavelmente Soren Kierkegaard se inscrevem, preocupa-se não com a existência ou mesmo com a legitimidade de Sua crença, porém com o valor que tal existência e/ou crença, a despeito de ser ou não o caso, representam. Nesse patamar, mostrar como pôde surgir a crença de que Deus existe e de que modo essa crença adquiriu peso e importância é uma questão distinta e que talvez "torna supérflua a contraprova de que Deus não existe" 28 .

É com tal olhar que Nietzsche suspeita que a tese de um mundo perfeitamente ordenado, do mecanicismo como linguagem cifrada do universo, da própria ideia de "leis da natureza", do finalismo cosmológico, de substâncias eternas, da realidade da "matéria", enfim, dos mais diversos modos de expressão e compreensão daquilo que conhecemos, sejam como que meras sombras de Deus. E ele se questiona, em seguida, "quando é que todas estas sombras de Deus não nos obscurecerão mais a vista? quando teremos desdivinizado completamente a natureza? quando poderemos começar a naturalizar os seres humanos com uma pura natureza, de nova maneira descoberta e redimida?"29. "Desdivinizar a natureza" consiste sobretudo

e muitos dos mais antigos filósofos gregos, de fato também chegaram àqueles conceitos; ou se somos nós que, bastante benevolentemente, os atribuímos a eles [...]. Uma tal investigação histórica teria livrado Kant da necessidade desagradável, na qual ele agora cai, quando faz aqueles três conceitos originarem-se necessariamente da natureza da razão e, contudo, verificar que são insustentáveis e não podem ser fundados; com isto, faz de toda razão mesma uma sofística [...]" [Crítica da Filosofia Kantiana, p. 606-608]. Ora, coaduna-se à posição de Schopenhauer que, sendo a ideia de Deus meramente regulativa e sem fundamento teórico, então talvez se possa conservar a subjetividade transcendental da nossa representação do mundo sem ela; ou seja, sequer precisaríamos dela como ideal regulativo. É justamente ao analisar a obra deste ateu e pessimista, suposto autor da "autêntica filosofia do cristianismo" [como o próprio Schopenhauer declama em sua "Contribuição à doutrina da afirmação e da negação do querer-viver”, §161], que Nietzsche reflete, por um tipo peculiar de estudo histórico, a "genealogia", as características de um caminho sinuoso que conduziu à ascensão e agora decadência da epistemologia divina. Com isso ele não propõe que a proliferação do ateísmo do século XIX seja uma consequência direta desta genealogia, mas sim que esta apresenta no âmbito conceptual a maneira como se deu o teocídio e quem foram - conscientes ou não - seus executores.

${ }^{28} \mathrm{~A} \$ 95$.

${ }^{29}$ GC $§ 109$. 
em abandonar um conjunto de categorias de pensamento associadas à fé religiosa, especialmente cristã, que permeia as "condições de possibilidade de toda experiência possível". Apesar do século XIX estimular a emancipação do discurso científico do teológico, persiste-se valorativamente com as mesmas concepções epistemológicas de quando Deus nos lançava seus favores e punições. O esforço de ruptura ideológica entre ciência e religião - e, quase que simultaneamente, entre a esfera pública e a religiosa - deixa a ciência e a cultura à beira de um abismo existencial. Isso porque, sem Deus, as noções epistêmicas que dele derivam e/ou lhe estão submetidas tornam-se etéreas e o pensamento se vê às voltas com estruturas que não têm mais sustentação. Para usar de uma imagem aproximada, é como se a forma como concebemos nossas crenças fosse um sistema lógico-dedutivo cujo axioma desaparece. Sem Deus, o homem não perde apenas a figura do Pai, mas sobretudo a si mesmo, pois mesmo sua autocompreensão deriva de uma divinização da natureza. Afinal, somos aqueles feitos à imagem e semelhança do Criador. Por isso, o núcleo da abordagem extramoral de Nietzsche apregoa que

"por mais importante que seja conhecer os motivos que realmente guiaram a conduta humana até hoje, talvez a crença neste ou naquele motivo, i.e., o que a humanidade presumiu e imaginou ser o autêntico motor do seu agir até agora, seja algo ainda mais essencial para o homem do conhecimento, pois a íntima miséria e felicidade é dada aos homens de acordo com a sua crença nestes ou naqueles motivos - não em virtude do que era realmente motivo!"30.

Logo, o que está em questão são os motivos pelos quais se crê. Todavia, não aqueles que "realmente" guiaram nossa conduta, mas os que "acreditamos" que efetivamente nos conduziram. Isso não significa em si a negação de uma instância metafísica, de uma "realidade" subjacente às crenças, porém a delimitação de quais tipos de "causas" interessam quanto a nossa "mais íntima miséria e felicidade" e de sua autonomia quanto à existência ou não de um âmbito transcendente. Indiferente, mesmo que por estratégia argumentativa, ao estatuto ontológico do que acreditamos, Nietzsche inclina-se sobre a investigação das condições e circunstâncias pelas quais nossas crenças atuam e sobre qual tipo de potência nelas se expressa. Aqui, com Gilles Deleuze, é fecundo distinguir entre a referência de um discurso e seu sentido. Enquanto a referência indica aquilo que o discurso denota, o sentido expressa as relações de dominação que o perpassam, a disposição vital que lhe caracteriza ${ }^{31}$. Daí que os ateus, por continuarem a valorizar as categorias de pensamento subdeterminadas à saudosa Divindade, são talvez os primeiros a se depararem com o fundo sem fundo para o qual a

${ }^{30} \mathrm{GC} \S 44$.

${ }^{31}$ DELEUZE, G. Nietzsche e a Filosofia, cap. I, §2. 
cultura se encaminha e, por conseguinte, aqueles que se põem na linha de frente deste novo campo de batalha. Daí o profundo esclarecimento do "louco do mercado", ao refletir se "a grandeza deste ato não é demasiado grande para nós".

Deve-se ter em mente que Nietzsche, diante desta constatação, concebe-a como um instante crítico na história da civilização ocidental, um momento que pode significar tanto a destruição quanto a reavaliação de todos os valores [Umwertung aller Werte]. Será o declínio caso não se consiga dar origem a novas formas de pensar e viver que substituam aquelas que se esvanecem. Entretanto, se a ausência Divina for tomada como um impulso para a criação de novos discursos, conceitos e valores, haverá um salto qualitativo na própria condição humana. Tomando-se a parábola da morte de Deus como uma questão epistemológica, compreende-se a necessidade de se reavaliar todo o conhecimento como uma das tarefas essenciais do pensamento contemporâneo. Mas o que significa reavaliar o conhecimento? O conhecimento é um valor? Em "Até onde vai a esfera da moral", seção d'A Gaia Ciência que dá continuidade a uma série de observações dedicadas à cognição, diz-se que "ao vermos uma nova imagem, imediatamente a construímos com a ajuda de todas as experiências que tivemos, conforme o grau de nossa retidão e equidade. Não existem vivências que não sejam morais, mesmo no âmbito da percepção sensível"32. Se cada novo conhecimento está estreitamente associado a todas as experiências que tivemos, se cada nova percepção é remetida e disposta às imagens que trazemos conosco e sobretudo à maneira como organizamos estas imagens conforme o grau de nossa retidão e equidade, parece adequado dizer que "não existem vivências que não sejam morais". Contudo, insista-se, "moral" aqui entendida não como "sentimento acerca do costume" ou "origem ou intenção que confere valor a uma ação", mas sim na acepção superior de âmbito das relações hierárquicas sob a quais se desenvolve o fenômeno vida. Nesta acepção vital, a moralidade é sempre uma disposição de valores. Assim, a cada novo estado de coisas se consubstancia uma hierarquia de valores que lhe é constituinte. Ou seja, há uma camada valorativa imanente à representação. Logo, todo ato de conhecer é primordialmente um ato de valorar, de hierarquizar, de "moralizar". Tal recondução do conhecimento à Vida parece justificável, pois se pode viver sem conhecer, porém não se pode conhecer sem viver ${ }^{33}$. Isto não significa uma mera redução do conhecer ao julgar e sim o reconhecimento de uma instância cognitiva em todo julgamento e, do mesmo modo, um aspecto valorativo em todo conhecimento. A moral, enquanto exame de constituições e hierarquias vitais, consiste numa investigação das ambíguas e por vezes instá-

\footnotetext{
32 GC $\$ 114$.

${ }^{33}$ CI II $\$ 10$.
} 
veis disposições de domínio e servidão entre um dado conjunto de crenças e volições, identificando em algumas proeminência em relação às outras num dado modo de vida. Os valores não persistem apenas nos objetos, mas igualmente nas categorias de conhecimento. A importância que damos à identidade e à quantificação, categorias sem as quais não poderíamos pensar em termos de objetos, é valorativa (moral) e não epistêmica. Desse ponto de vista, valorar nos conduz a um território anteepistemológico. A questão ante-epistêmica aqui não é se tais categorias são ou não essenciais para como pensamos, mas qual o valor, sob a ótica do fenômeno vida, do modo de pensamento que se constituiu em torno destas categorias.

Retomando-se a parábola, se Deus está morto, morto com Ele também está o valor do conhecimento que até então orientou nossa visão de mundo. $\mathrm{E}$ isto significa que as categorias epistêmicas em ato, as sombras de Deus, sem seu Fundamento, perderam seu valor, sua probidade. Entende-se assim a urgência ainda não percebida pelos "ateus" de agora dar novo propósito tanto à moral quanto ao conhecimento. Esta necessidade apenas atesta que o antigo alicerce, Deus, não está mais presente, e que é preciso algo para substituí-lo - um "outro" Deus. Porém, nenhum outro pode substituí-lo, pois o que se perdeu foi o próprio lugar do fundamento.

Mas o que significa enfim este processo de reavaliação ou, segundo o vocabulário de Nietzsche, "reavaliação do valor" do conhecimento? Quanto a isso, não nos é fornecida uma resposta direta. Atentando-se às tendências que o operador indica, pode-se ter em mente pelo menos duas possibilidades:

R1: Reavaliar o valor do conhecimento diz respeito à criação de novas categorias e objetos epistêmicos;

R2: Reavaliar o valor do conhecimento consiste em reordenar as categorias e objetos epistêmicos.

Considero R1 uma solução insatisfatória, pois a mera criação de novas categorias não é condição suficiente para que estas também não estejam sob a mesma hierarquia de valores que se deseja rejeitar. Assim, desdivinizar a natureza não me parece implicar em sua "materialização" ou algum recurso correlato. O problemático não é a efetividade de determinadas categorias e objetos, contudo o valor que a elas se atribui. Por isso, R2 soa adequada para com as pretensões de Nietzsche. Reavaliar os valores do conhecimento não é necessariamente uma mudança fática das categorias e dos objetos, contudo um deslocamento de seu sentido - uma subversão hierárquica. Aqueles deixam de ser tomados enquanto uma condição de possibilidade de todo o conhecimento e que nos conduzem necessariamente a pensar em Deus, revistos numa perspectiva humana, demasiado humana. Como tal reordenação requer a destruição ou desvaloração da or- 
dem anterior, entende-se por que Nietzsche considera que seu "prazer em destruir" esteja a obedecer a sua natureza afirmativa "que não sabe [ou mesmo não pode] separar o dizer Sim do fazer Não"34. Tal opção parece a que melhor descreve a sugestão de desdivinização do real. Daí que o projeto central da filosofia de Nietzsche pode ser reformulado como a tentativa de dar um sentido ao homem num mundo que já não tem sentido algum. Esta intuição parece correta, principalmente se atentarmos que a parábola da morte de Deus é justamente a constatação de que as antigas formas de dar sentido ao mundo perderam sua força vital. Assim, para uma hipotética epistemologia nietzscheana, o conhecimento, pensado mesmo que precariamente enquanto um conjunto de categorias que recobrem e ordenam nossa visão de mundo, consiste numa das manifestações de nossos esforços de conservar e fortalecer a vida. Mas será possível realizar tal reavaliação de todos os valores? A estratégia de Nietzsche é mostrar que a dúvida não diz respeito à possibilidade ou não de realizar a reavaliação de todos os valores e sim se é possível realizá-la mais uma vez e sob nova perspectiva, pois, de acordo com o argumento da primeira dissertação da Genealogia da Moral, coube aos sacerdotes cristãos uma decisiva reavaliação de todos os valores quando estes inverteram reativamente a hierarquia de valores do mundo antigo. Como é consensual mesmo para os cristãos que de fato houve uma ruptura e inversão dos valores senhoriais quando da nova aliança, então Nietzsche encontra um indício de que uma reavaliação agora ativa talvez também possa ser o caso.

Falou-se, em distinção à divinização epistemológica, em se subscrever o conhecimento à perspectiva humana. $\mathrm{O}$ que isto significa? N'A Gaia Ciência, na contundente seção "Nosso novo "infinito" 35 , analisam-se as condições pelas quais se pode examinar a "objetividade" de nossas experiências. Diz-se ali que não podemos, mesmo pela mais cuidadosa investigação, determinar até onde vai o caráter perspectivista da existência, se ela tem algum outro caráter, um "real" para além de qualquer interpretação ou sentido. Ironiza-se mesmo esta ideia questionando-se se um suposto real para além daquilo a que se pode conceder sentido não seria algo "sem-

\footnotetext{
${ }^{34} \mathrm{EH}$, "Por que sou um destino" §2.

35 GC §374: "Até onde vai o caráter perspectivista da existência, ou mesmo se ela tem algum outro caráter, se uma existência sem interpretação, sem 'sentido', não vem a ser justamente um 'absurdo'; se, por outro lado, toda existência não é essencialmente interpretativa - isso não pode, como é razoável, ser decidido nem pela mais diligente e conscienciosa análise e autoexame do intelecto: pois nesta análise o intelecto não pode deixar de ver a si mesmo sob suas formas perspectivas e apenas nelas [...] $\mathrm{O}$ mundo tornou-se novamente infinito para nós na medida em que não podemos rejeitar a possibilidade de que ele encerre infinitas interpretações [...] quem teria vontade de divinizar de novo, à maneira antiga, esse monstruoso mundo desconhecido? [...] estão incluídas demasiadas possibilidades não-divinas de interpretação nesse desconhecido".
} 
sentido". Isto porque, quando se empreende tal deliberação, "o intelecto não pode deixar de se ver por suas formas perspectivas e apenas nelas". Logo, assim formulado, o chamado perspectivismo é aqui a tese de que não se pode negar a possibilidade de que o mundo encerre infinitas interpretações. A impossibilidade lógica de se negar sua existência não significa que haja infinitas interpretações e muito menos que estas sejam de igual valor. Toda a linha argumentativa se desvia de qualquer consideração ontológica em sentido estrito. Não se discute como o mundo é, mas as condições pelas quais é possível lhe conceder sentido. Não poder rejeitar a possibilidade de que o mundo encerre infinitas interpretações, mesmo não consistindo numa prova de que efetivamente existem infinitas interpretações, torna contraditória a proposta de que há necessariamente apenas uma perspectiva, apenas uma epistemologia e hierarquia possíveis, a saber, aquelas que divinizam a natureza. Uma vez que a epistemologia divina se exige como única, o perspectivismo, sem rejeitá-la diretamente, apenas pela possibilidade lógica de ser o caso, desmerece as pretensões de um projeto que visa as condições universais e necessárias de possibilidade da experiência. Ou seja, se K considera que há como que uma condição de possibilidade para $x$, para refutá-lo, "basta" que $\mathrm{N}$ mostre que há pelo menos mais uma possibilidade de se interpretar $x$, independente de qual destas seja a verdadeira ${ }^{36}$.

\footnotetext{
${ }^{36}$ A caracterização aqui apresentada da doutrina perspectivista de Nietzsche a partir dos escritos publicados e/ou preparados para publicação diverge das interpretações equivocamente elaboradas preponderantemente com base nas mencionadas notas preparatórias, como se dá, e.g., em António Marques, A Filosofia Perspectivista de Nietzsche, bem como em Sílvia P. M. Rocha, Os Abismos da Suspeita: Nietzsche e o perspectivismo (provavelmente os principais trabalhos publicados em língua portuguesa acerca da tópica). Não é o caso sequer de criticar a reconstituição e inferências que Marques e Rocha fazem da doutrina perspectivista segundo o material não autorizado para publicação, porém de recusar que a fonte bibliográfica principal que guia tais leituras seja apropriada para a compreensão da hipótese perspectivista de Nietzsche. É a concessão de estatuto hermenêutico privilegiado ou de igual relevância entre as notas preparatórias e os trabalhos publicados e/ou preparados para publicação o que conduz Marques a acreditar que a doutrina perspectivista seria apenas uma continuação do projeto crítico-transcendental de Kant (ver "Para uma genealogia do perspectivismo", introdução à antologia de notas preparatórias de Nietzsche acerca de "teoria do conhecimento" organizadas por Marques sob o título Sujeito e Perspectivismo) e Rocha a tentar mostrar que o perspectivismo retoma uma tradição cética e sofística que concebe a "relatividade" de todo o conhecimento. Pela argumentação acima, desenvolvida por obra autorizada e publicada pelo próprio Nietzsche, a hipótese do perspectivismo não dá prosseguimento ao projeto transcendental e sim o refuta ao contestar que se possam estabelecer as tais condições a priori da experiência. Por outro lado, Nietzsche não pretende relativizar o conhecimento com a doutrina perspectivista e assim meramente alcançar alguma suspensão de juízo, já que do fato do mundo ter infinitas interpretações não se segue que todas sejam corretas e/ou tenham o mesmo valor - se fosse assim, Nietzsche sequer poderia objetar a superioridade sob a ótica da Vida das interpretações "desdivinizadas" em relação às "divinizadas". Daí que Nietzsche, na terceira dissertação da Genealogia da Moral, aconselha que "de agora em diante, senhores filósofos, guardemo-nos bem contra a antiga e perigosa fábula conce-
} 
Mas se o valor para a vida de um conhecimento não está sobretudo em sua verdade ou falsidade, não seria ainda apropriado, para escapar dos riscos do ateísmo esclarecido, "divinizar à maneira antiga"? Por que a busca pelo sentido da existência recusaria agora qualquer apelo à transcendência? Mesmo que uma perspectiva divina como a aqui em litígio fosse em relação ao que podemos conhecer tão apropriada como qualquer outra nãodivina, quanto a sua condição vital, quanto ao tipo de relações de dominação que lhes conferem sentido, as diferenças entre ambas continuariam irreconciliáveis. Somente quem considera que o valor de algo se reduz ao modo como conhecemos pode julgar que a ausência de critérios de verdade/falsidade significa uma impossibilidade de distinção valorativa entre duas ou mais interpretações. Não que verdade/falsidade não sejam critérios, mas, quanto ao valor de algo, não são os únicos e sequer os mais importantes. Talvez por isso Nietzsche entenda que reconhecer a inverdade como também condição para a vida seja por si suficiente para que uma filosofia se ponha além do bem e do $\mathrm{mal}^{37}$. Tendo-se em vista o diagnóstico filosófico estruturante da parábola da morte de Deus, a saber, o declínio do lugar da divindade enquanto fundamento de como conhecemos e moralizamos, ao se tomar consciência de que foram estas próprias formas de pensamento divinizado que conduziram ao seu descrédito - afinal, foi através delas que se chegou ao ateísmo, à desvalorização dos valores cristãos e, espera-se, a sua revaloração -, percebe-se por que, como sugere Nietzsche, não se pode mais "divinizar à maneira antiga": que o mundo encerre infinitas interpretações não quer dizer que todas sejam capazes de lhe dar sentido; algumas perspectivas, como a epistemologia divina, revelam-se inclusive como modos de lhe retirar o sentido. Daí por que, para Nietzsche, hoje "o ateísmo e uma espécie de segunda inocência são

ptual que estabelece um 'puro sujeito do conhecimento, isento de vontade, alheio à dor e ao tempo', guardemo-nos dos tentáculos de conceitos contraditórios como 'razão pura', 'espiritualidade absoluta', 'conhecimento em si' - tudo isso pede que se imagine um olho que não pode absolutamente ser imaginado, um olho voltado para nenhuma direção, no qual as forças ativas e interpretativas, as que fazem com que ver seja ver-algo, devem estar imobilizadas, ausentes; exige-se do olho, portanto, algo absurdo e sem sentido [notese que estes foram os termos empregados na GC \$374 acima para condenar a mesma tentativa de ir além de qualquer perspectiva]. Existe apenas uma visão perspectiva, apenas um 'conhecer' perspectivo; e quanto mais afetos permitirmos falar sobre uma coisa, quanto mais olhos, diferentes olhos, soubermos utilizar para essa coisa, tanto mais completo será nosso 'conceito' dela, nossa 'objetividade"' [GM, III §12]. Através do destaque por itálico ou aspas, Nietzsche reúne e desloca o sentido de termos como "conhecer", "conceito" e "objetividade", bem como questiona a ideia de se ter "apenas" uma visão perspectiva (negando que se trate aqui de um relativismo vulgar), deixando bastante claro como sua "doutrina" perspectivista se opõe a uma filosofia transcendental ("guardemonos de conceitos contraditórios como 'razão pura") ou da mera subjetividade cética ou sofística, porquanto o alcance da objetividade não se dá com apenas um olhar, mas com quanto mais afetos e "olhos" [perspectivas] permitirmos falar sobre uma coisa.

$37 \mathrm{BM} \S 4$ 
inseparáveis" ${ }^{\prime 38}$. A despeito de que o ateísmo seja inseparável e condição necessária para a citada segunda inocência, não se trata de uma condição suficiente, justificando assim que a parábola da morte de Deus lhe seja anunciada.

Se é correto que tais oposições já estejam presentes em ato desde a primeira obra de Nietzsche, apenas posteriormente se lhe aparecem como pensamento refletido. Esta ordem de descoberta - cronológica -, pelo próprio movimento interno do discurso filosófico de Nietzsche, não lhe soa como uma objeção a sua ordem de reflexão - propriamente filosófica -, já que "raramente nos tornamos conscientes do verdadeiro páthos de cada período da vida enquanto nele estamos", pois tendemos a achar que "ele é o único período possível e razoável para nós, algo duradouro ou definitivo e não o que geralmente é, algo transitório e passivo" 39 . Assim, a "tarefa" ou "destinação" de uma filosofia acontece numa obra "muito antes dela ter em vista e saber esta tarefa pelo nome" ${ }^{\prime 4}$. O que Nietzsche finalmente descobre é que aquilo que sempre o ocupou mais profundamente foi o problema da decadência, a questão acerca das formas superiores e inferiores de vida ${ }^{41}$. Como Nietzsche realiza tal investigação? Basicamente por um exame acerca de como esta ou aquela forma de vida se relaciona com a própria vida, i.e., se a afirma ou a nega. Esta tópica tem sua origem conceptual na quarta parte d'O Mundo como Vontade e como Representação, na qual Schopenhauer defende a grandiosidade de uma existência ascética por esta se constituir pela negação dos impulsos vitais, única forma de sofrer menos naquele que é o pior dos mundos possíveis. O que Schopenhauer descreve como "grandiosidade" é a condição pela qual alguns conseguiram superar o sofrimento inerente à própria existência, livrando-se inclusive da ilusão de tranquilidade pela consumação dos prazeres. Afinal, tal consumação é incapaz de evitar o retorno do desejo e, por conseguinte, da insatisfação e da angústia. O esforço de Nietzsche, entendendo Schopenhauer como aquele que melhor soube apresentar as intuições dos mais "sábios", é justamente contestar o valor existencial do ascetismo enquanto negação da vida, mostrando, pelo contrário, que a afirmação incondicional da vida é o caminho para a elevação do homem, para um "super-homem". Num passo estratégico até aqui ignorado pela recepção crítica, Nietzsche encontrou o moto para iniciar tal contestação ao seu antigo "mestre" justamente na indicação deste de que, enquanto a sua doutrina da negação da vontade de viver, mesmo sem Deus, seria a autêntica filosofia do cristianismo (já que a busca dos cristãos pela transcendência implica necessariamente nesta negação dos impulsos vitais, pois o sentido

\footnotetext{
38 GM, II $\$ 20$.

39 GC $\$ 317$.

${ }^{40} \mathrm{HH}$, prólogo $\$ 7$.
} 
destes reside tão-somente num "outro mundo", o que, em linguagem schopenhaueriana, seria o mundo visto como "Vontade"), por sua vez, os gregos, mais precisamente, os gregos da época trágica, estariam à antípoda desta negação da vontade de viver por afirmarem a vida, ao tornarem "belo" o que há de mais terrível na existência.

Daí Nietzsche ter escrito O Nascimento da Tragédia justamente para pensar sobre "a relação dos gregos com a dor" e a possibilidade de que aquela "loucura dionisíaca" seja fruto de uma "saúde transbordante, de uma plenitude demasiado grande", ou seja, de uma suprema afirmação da vida. Justamente para se contrapor ao cristianismo, que "foi desde o início, essencial e basicamente, asco e fastio da vida, que apenas se disfarçava, apenas se ocultava, apenas se enfeitava sob a crença em 'outra' ou 'melhor' vida", Nietzsche revela que o "hostil silêncio" com que seu primeiro livro trata o cristianismo é uma forma de contrapor, em "prol da vida", "uma contradoutrina e uma contravaloração da vida, puramente artística, anticristã ${ }^{\prime 42}$. Sequer se tratava ali de tomar os valores artísticos como, em si mesmos, superiores à moral cristã, mas de indicar como os valores estéticos da tragédia grega, enquanto afirmação da vida, eram superiores aos da moral cristã ${ }^{43}$. Superiores para quê? Não para quê, mas para quem. Para a criação de um tipo nobre, de um homem plenamente realizado. Por isso, nas primeiras seções do polêmico $O$ Anticristo, Nietzsche esclarece que o seu problema diz respeito a "que tipo de homem deve-se cultivar, deve-se querer, como de mais alto valor, mais digno de vida" e de como este projeto se contrapõe ao que lhe parece ter sido alcançado pela moral cristã, a saber, "o tipo oposto: animal doméstico, o animal de rebanho, o animal doente - o cristão" ${ }^{\prime 4}$. Mas enfim, por que a negação dos impulsos vitais manifestaria um tipo inferior ao gerado pela afirmação incondicional da vida? Por que, sob a ótica do fenômeno vida, a negação da vontade de viver representa uma obstrução, degeneração e veleidade da própria existência que se exprime neste ou naquele modo de existir (seja um homem,

\footnotetext{
${ }^{41} \mathrm{CW}$, prólogo.

${ }^{42} \mathrm{NT}$, "Tentativa de autocrítica" $\$ 4-5$

${ }^{43}$ Seguindo-se a ordem de reflexão de Nietzsche, é correto indicar que a Genealogia da Moral apresenta, a partir da contradoutrina e contravaloração já entrevista desde $O$ Nascimento da Tragédia, o estudo decisivo de por que o cristianismo "foi desde o início, essencial e basicamente, asco e fastio da vida, que apenas se disfarçava, apenas se ocultava, apenas se enfeitava sob a crença em 'outra' ou 'melhor' vida"; e que $O$ Anticristo seria, como o próprio Nietzsche declarou, o instante em que se estabelece a reavaliação de todos os valores, no caso, os valores cristãos. Logo, Nietzsche não desenvolve uma crítica do cristianismo para dela reavaliar todos os valores - isto seria exatamente o que os sacerdotes empreenderam reativamente quando da ascensão do cristianismo -, mas sim, de uma visão trágica, contrapor ativamente a distância existencial (o "páthos da distância”) entre as contundentes formas de afirmação e negação da vida.

${ }^{44} \mathrm{AC} \S 3$.
} 
uma comunidade, uma era), enquanto a afirmação da vontade de viver mostra o crescimento, fortalecimento e "saúde" deste ou daquele modo de existir. Isso pressupõe ou meramente constata a discutida tese de que a vida é "instinto de crescimento, de duração, de acumulação de forças, de poder" e que, por isso, "onde falta a vontade para o poder [Wille zur Macht], há declínio" ${ }^{45}$. Mas a própria reprodução humana, com a fertilização do ovócito secundário por um espermatozoide dentre milhões, bem como todo o processo normal de desenvolvimento embrionário, já não mostram suficientemente o surgimento da vida como crescimento, fortalecimento e saúde? E, por outro lado, em diversos casos de desenvolvimento embrionário anormal, não se manifesta por vezes uma supressão do fenômeno vida, sua degeneração, enfraquecimento e enfermidade? Assim, para Nietzsche, a obstrução dos impulsos vitais, inerente à negação da vontade de viver, representa enfraquecimento e enfermidade, enquanto a afirmação da vontade de viver ou poder significa o fortalecimento e saúde de um modo de existir. Não se trata, contudo, de uma redução do existencial ao fisiológico, mas da elevação da fisiologia a uma expressão filosófica da existência ("physiologia"). Que os cristãos sejam levados a dar sentido a este mundo apenas por referência a um "outro mundo" mostra, tanto para Schopenhauer quanto para Nietzsche, que estes negam este mundo. Se para Schopenhauer isso indicaria uma superioridade existencial do cristianismo, para Nietzsche revela o quão vil é o modo de vida cristão.

Isso faria de Nietzsche um ateu? Cabe esclarecer certa equivocidade do termo "ateísmo". Em sua acepção clássica, "ateu" diz respeito não àqueles que desacreditam da existência dos deuses, mas sim aos que não são devotos de nenhuma divindade. Parece assim apropriado distinguir este ateísmo clássico daquela outra forma de ateísmo de ocorrência ou preponderância moderna segundo a qual "ateu" é aquele que não acredita na existência de Deus ou dos deuses ${ }^{46}$. É naquele sentido original que Zaratustra pode ser um ateu e, ao mesmo tempo, admitir que acreditaria num Deus que soubesse dançar ${ }^{47}$. Assim, a parábola da morte de Deus merece ser

\footnotetext{
${ }^{45} \mathrm{AC} \$ 6$.

${ }^{46}$ Segue-se aqui a caracterização proposta por Michael Martin em sua introdução ao The Cambridge Companion to Atheism. Por conveniência expositiva, deixam-se de lado bifurcações mais sutis, como, e.g., a qualificação como "ateu" a quem não acredita nos atributos que a Igreja cristã apregoa a Deus.

${ }^{47}$ GM, II §25; Z, "Do ler e do escrever”. Nietzsche, em GM §19-22, ao refazer a relação genealógica entre a ideia de Deus e a "má-consciência”, revela em seguida "que em si a concepção de deuses não conduz necessariamente a essa depravação da fantasia que tivemos de considerar por um instante, que existem maneiras mais nobres, que não seja para essa violação e autocrucificação do homem, na qual os últimos milênios europeus demonstraram sua mestria - isto se pode felizmente concluir a todo olhar lançado aos deuses gregos, esses reflexos de homens nobres e senhores de si, nos quais o animal no homem se sentia divinizado e não se dilacerava, não se enraivecia consigo mesmo! Por
} 
interpretada como a constatação de que, conquanto haja cada vez mais pessoas que duvidam ou rejeitam a existência de Deus, por ainda continuarem devotas dos valores morais associados à divindade - o que se poderia chamar, com Nietzsche, de "sombras de Deus" -, elas se encontram diante de um momento crucial pela perda do que até ali constituía a fundamentação última de todos os seus valores.

Vários pensadores, a despeito da verdade ou falsidade da existência de Deus, consideraram que a religião era fundamental para assegurar a paz e a estabilidade social. A parábola da morte de Deus anuncia também que esta pia fraus não tem mais a influência de antes e que é preciso preparar as pessoas - ou ao menos certas pessoas - para este mundo desdivinizado. Isto não significa que a religião esteja por se extinguir e será substituída por uma existência desencantada, mas sim que não possui ou possuirá mais a força que até aqui pareceu indispensável para a autocompreensão do humano. Nietzsche, ao mesmo tempo que celebra a queda da epistemologia divina por suas possibilidades para fortalecimento e crescimento do homem, busca advertir os executores e descendentes desta façanha sobre as consequências funestas de tal ato, convicto de que este pode ser tanto um momento final de decadência quanto uma ascensão e autossuperação da vida. Daí destinar a citada parábola aos ateus, aqueles que primeiro são atingidos pela "boa-nova" e, por conseguinte, os mais ameaçados pelo niilismo, i.e., a incapacidade de dar sentido ao homem num mundo que talvez não tenha mais sentido algum. E quanto aos crentes? Do ponto de vista sociológico, terão que se deparar com uma classe de descrentes e de valores que exigem ser reconhecidos e mesmo protegidos pelo Estado; do ponto de vista filosófico, talvez um dia sejam incapazes de ignorar a decadência da epistemologia divina, sendo assim levados ao mesmo abismo em que hoje já se encontram os ateus.

\section{Repertório bibliográfico}

ALLISON, H. Kant's Transcendental Idealism: an interpretation and defense. New Haven; London: Yale University, 1983.

BENTO XVI, Deus é Amor (Carta-Encíclica do Santo Padre). São Paulo: Editora Paulus/ Loyola, 2006.

DELEUZE, G. Nietzsche e a Filosofia. Rio de Janeiro: Ed. Rio, 1976.

A Lógica do Sentido. São Paulo: Perspectiva, 2009.

muito e muito tempo, esses gregos se utilizaram dos seus deuses para manter afastada a 'má-consciência', para poder continuar gozando a liberdade da alma: uso contrário, portanto, ao que o cristianismo fez com o seu Deus [GM §23]. 
DESCARTES, R. Discurso do Método. In: Obras reunidas. Coleção Os Pensadores. São Paulo: Abril Cultural, 1973.

DIOGENES LAERTIUS. Vidas e Doutrinas dos Filósofos Ilustres. $2^{\mathrm{a}}$. ed. Brasília: Editora UnB, 2008.

ELIA, S. Preparação para a Linguística Românica. Rio de Janeiro: Acadêmica, 1974.

HEIDEGGER, M. "Identidade e Diferença". In: Conferências e Escritos Filosóficos. Coleção Os Pensadores. São Paulo: Abril Cultural, 1973.

HOLLINGDALE, R. Nietzsche: The man and his philosophy. New York; Cambridge: Cambridge University Press, 1999.

HUME, D. Tratado da Natureza Humana. São Paulo: Unesp, 2009.

GIL, F [Org.]. Recepção da Crítica da Razão Pura. Lisboa: Fundação Calouste Gulbenkian, 1992.

LEBRUN, G. Kant e o Fim da Metafísica. São Paulo: Martins Fontes, 1993.

KANT, I. Critica da Razão Pura. 4. ed. Lisboa: Fundação Calouste Gulbenkian, 1997. . Prolegômenos a toda Metafísica Futura. Lisboa: Edições 70, 2008.

KAUFMANN, W. Nietzsche, Philosopher, Psychologist, Antichrist. 4. ed. Princenton: Pricenton University Press, 1974.

MARQUES, A. Sujeito e Perspectivismo (seleção de textos de Nietzsche sobre teoria do conhecimento). Lisboa: Publicações Dom Quixote, 1989.

A Filosofia Perspectivista de Nietzsche. São Paulo: Discurso, 2003.

MARTIN, M. The Cambridge Companion to Atheism. New York; Cambridge: Cambridge University Press, 2007.

MONTINARI, M. "Interpretações nazistas". In: Cadernos Nietzsche 07, p. 55-77, 1999. Disponível em http://www.fflch.usp.br/df/gen/pdf/cn_07_04.pdf_acessado em 31/05/2011].

NIETZSCHE, F. O Nascimento da Tragédia ou Helenismo e Pessimismo [NT]. São Paulo: Companhia das Letras, 2003.

Da Utilidade e dos Inconvenientes da História para a Vida [CE II]. In: Considerações Intempestivas I-II. Lisboa/São Paulo: Editorial Presença / Martins Fontes, 1976.

. Humano, Demasiado Humano: um livro para espíritos livres [HH]. São Paulo: Companhia das Letras, 2000.

Aurora: reflexões sobre os preconceitos morais [A]. São Paulo: Companhia das Letras, 2004.

A Gaia Ciência [GC]. São Paulo: Companhia das Letras, 2002.

. Assim Falou Zaratustra [Z]. São Paulo: Civilização brasileira, 1998.

. Além do Bem e do Mal: prelúdio a uma filosofia do futuro [BM]. $2^{\mathrm{a}}$.

Ed. São Paulo: Companhia das Letras, 2003.

140 Sintese, Belo Horizonte, v. 39, n. 123, 2012 

das Letras, 1999.

A Genealogia da Moral: uma polêmica [GM]. São Paulo: Companhia O Caso Wagner [CW] / Nietzsche Contra Wagner. São Paulo: Companhia das Letras, 1999. Crepúsculo dos Ídolos [CI]. São Paulo: Companhia das Letras, 2007. . Ecce Homo [EH]. São Paulo: Companhia das Letras, 2000. . O Anticristo [AC] / Ditirambos de Dionísio. São Paulo: Companhia das Letras, 2007.

LEBRUN, G. Kant e o Fim da Metafísica. São Paulo: Martins Fontes, 1993.

PLATÃO. “O Sofista". In: Diálogos. São Paulo: Abril Cultural, 1972, p. 135-203.

ROCHA, S. Os Abismos da Suspeita: Nietzsche e o Perspectivismo. Rio de Janeiro: Relume-Dumará, 2003.

SAMPAIO, E. Por que Somos Decadentes? Afirmação e Negação da Vida Segundo Nietzsche. Brasília: Editora UnB, 2012 (no prelo).

SCHOPENHAUER, A. Crítica da Filosofia Kantiana. In: O Mundo como Vontade e como Representação. São Paulo: Unesp, 2005, apêndice.

Endereço do Autor:

SHIN, CA 2, Bloco B, Ap. 227,

Ed. Monumental, Lago, Norte

71503-502 Brasília - DF

e-mail: evaldosampaio@hotmail.com 